Saudi Journal of Oral and Dental Research

Abbreviated Key Title: Saudi J Oral Dent Res

ISSN 2518-1300 (Print) |ISSN 2518-1297 (Online)

Scholars Middle East Publishers, Dubai, United Arab Emirates

Journal homepage: http://scholarsmepub.com/sjodr/

Original Research Article

\title{
Knowledge, Awareness about Dental Flossing Among Adult Population in Saudi Arabia
}

\author{
Osama Ahmad Almassri ${ }^{1 *}$, Laila Mohammed Alanazi ${ }^{2}$, Jehan Nwar Almutiri ${ }^{3}$, Saud Ismail Asirri ${ }^{4}$, Fatima Sultana ${ }^{5}$, Dalal \\ jumah alturaif ${ }^{6}$
}

${ }^{1}$ The clinics Medical center, Riyadh, Saudi Arabia
${ }^{2}$ Al Farabi Hospital, Riyadh, Saudi Arabia
${ }^{3}$ Buraydah Private Colleges, Qassim, Saudi Arabia
${ }^{4}$ Al Farabi Hospital, Jeddah, Saudi Arabia
${ }^{5}$ Research Centre, Riyadh, Saudi Arabia
${ }^{6}$ Al Farabi Hospital, Riyadh, Saudi Arabia

DOI: $10.36348 /$ SJODR.2019.v04i12.001

| Received: 02.11.2019 | Accepted: 11.11.2019 | Published: 09.12.2019

*Corresponding author: Dr. Osama Ahmad Almassri

\section{Abstract}

To remove the inter-proximal plague, flossing has received the most attention among all the dentists. However, difficulty in dental flossing has made this technique to be avoided during tooth brushing. The proper transfer of Information and motivation to use dental floss and brush can change the attitude of the patient from an unhealthy approach to a healthy approach. The main aim of this study is to assess the knowledge and awareness of the adult population in Saudi Arabia about dental flossing. The pre-designed, pre-tested, and self-administered questionnaire survey was conducted among the adult patients visiting the various clinics in Saudi Arabia. The data that was collected from the questionnaire were analysed using the computer software Statistical package for social sciences that is SPSS 16. Among these 1011 patients, most of them were in the age group ranging from 19 to 25 years. About 971 (55\%) participants used toothbrush and toothpaste to clean their teeth, while $234(23 \%)$ patients used mouthwash, and $177(17 \%)$ used miswak. Only $140(14 \%)$ participants used the dental floss, $566(56 \%)$ didn't use dental floss, and 305 (30\%) rarely use dental floss.

Keywords: Plague, dental floss, periodontal diseases, gingivitis, toothbrush, miswak, oral hygiene.

Copyright @ 2019: This is an open-access article distributed under the terms of the Creative Commons Attribution license which permits unrestricted use, distribution, and reproduction in any medium for non-commercial use (NonCommercial, or CC-BY-NC) provided the original author and source are credited.

\section{INTRODUCTION}

The process of maintaining a healthy mouth by regular cleaning that is by Brushing and flossing is called oral hygiene. Oral hygiene is used to prevent tooth decay and gum disease. According to good oral health is a condition that is free from chronic oral, facial pain, type of oral cancers, oral sores, cleft lip and palate, gum diseases, tooth decay, and tooth loss [1]. The significant etiological factor for periodontal disease is bacterial plaque.

The dental floss is used to clean the plague in the inter-dental regions. Among the most common methods of removal of the plague is the brushing of the tooth. The brush alone doesn't have access to the interdental regions of the dentition; this keeps part of the dentition to be unclean [2]. For the inter-proximal plague, flossing has received the most attention among all the dentists. However, difficulty in dental flossing has made this technique to be avoided during tooth brushing.
Hence the awareness about dental flossing is to be made among the patients to avoid periodontal and gingival diseases [3]. The proper information about oral conditions, the risk factors, and measures need to be provided to the patients. The appropriate transfer of Information and motivation to use dental floss and brush can change the attitude of the patient from an unhealthy approach to a healthy approach. The oral health diseases can be prevented by improving the knowledge of the community regarding oral hygiene by using a toothbrush and dental floss. The major obstacle faced by the dentist about the oral health of the population is the lack of proper knowledge and attitude of the patient towards oral hygiene [4].

In order to eradicate the dental disease from the population, it's essential to determine the status of the attitude and knowledge about the dental flossing technique among the adult population of Saudi Arabia. Thus, the present study aims to identify the knowledge, 
awareness about dental flossing among the adult population in Saudi Arabia.

\section{AIM \& OBJECTIVES}

The main aim of this study is to assess the knowledge and awareness of the adult population in Saudi Arabia about dental flossing. This aim can be attained by:

- $\quad$ Surveying to evaluate the knowledge of the adult population residing in Saudi Arabia about dental flossing.

- To determine the attitude and awareness of the adult Saudi population regarding dental floss use.

- Identifying the relationship between the age of the patient and the ease or problems related to use the dental floss.

- Identifying the relationship between the Gender of the patient and the use of dental flossing.

- Determining awareness among adult patients belonging to varied nationalities residing in Saudi Arabia.

\section{METHODOLOGY \\ Research instrument}

The pre-designed, pre-tested, and selfadministered questionnaire survey was conducted among the adult patients visiting the various clinics in Saudi Arabia. The adult population of Saudi Arabia had to answer the questionnaire to determine the knowledge and awareness of dental flossing. This survey was conducted from a period from 2018-2019.

The questionnaire was both in Arabic and English language. The survey included 24 questions to collect the demographic data of the patients and also to determine the knowledge and awareness about the dental flossing. Adult patients visiting dental clinics in Saudi Arabia were asked to participate in the survey and answer the questionnaire.

About 1011 adult patients answered the questions of the survey. The inclusion criteria for the study were any patient above 18 years of age, the patient should be of Saudi nationality, and only human beings were considered for this survey. The exclusion factors were non-human patients, patients from other nationality than Saudi, patients below 18 years of age.

\section{STATISTICAL METHODS}

The data that was collected from the questionnaire were analysed using the computer software Statistical package for social sciences that is SPSS 16. The frequencies and percentages of the responses from the adult population in Saudi Arabia were done using the P-value equal to or less than 0.05 . The descriptive statistics were attained, and the mean, standard deviation, and frequency distribution were calculated.

\section{RESULTS}

The knowledge and awareness about the dental flossing among the adult population in Saudi Arabia were determined based on a questionnaire. The questionnaire included 24 questions related to the demographic status of the patient and their knowledge about dental flossing. About 1011 adult patients in Saudi Arabia participated in the survey and answered the questionnaire.

\section{Demographic Data}

Among these 1011 patients, most of them were in the age group ranging from 19 to 25 years. About $482(47 \%)$ belong to this age group. The majority of the patients were females, about 702, which accounts for $70 \%$ of the total participants, whereas the males account for the remaining 30\% that is 309 patients. Most of the patients, about 445 (45\%) had qualifications of Secondary School; about 89 patients had no education. The majority of the participants of the survey were residing in Riyadh City, approximately 389 patients followed by Makkah (167), Aseer Province (110), Qassim (102), Eastern province (97) and many more.

\section{Knowledge about Oral Hygiene}

Around 381 (39\%) patients clean their teeth twice a day, followed by $329(33 \%)$ patients clean their teeth once a day, and about $27(2 \%)$ participants never cleaned their teeth. About 971 (55\%) participants used toothbrush and toothpaste to clean their teeth, while 234 (23\%) patients used mouthwash, and $177(17 \%)$ used miswak. About 570 (46\%) patients use circular motion of the toothbrush to brush their teeth. A maximum of $406(35 \%)$ use dental floss as a secondary method for plague control, and 306 patients (25\%) use toothpicks. 
Table-1: Knowledge and Awareness of the adult population in Saudi Arabia about the Dental Floss

\begin{tabular}{|c|c|c|}
\hline Questions related to the Demographic status of the Patient & Frequency & Percentage (\%) \\
\hline $\begin{array}{l}\text { 1. Age of the patient } \\
19-25 \text { years } \\
<18 \text { years } \\
26-35 \text { years } \\
36-45 \text { years } \\
46-55 \text { years } \\
>55 \text { years }\end{array}$ & $\begin{array}{l}482 \\
286 \\
185 \\
41 \\
15 \\
0\end{array}$ & $\begin{array}{l}47 \\
28 \\
18 \\
4 \\
1 \\
2\end{array}$ \\
\hline $\begin{array}{l}\text { 2. Patient's age } \\
\text { Female } \\
\text { Male }\end{array}$ & $\begin{array}{l}702 \\
309\end{array}$ & $\begin{array}{l}70 \\
30\end{array}$ \\
\hline $\begin{array}{l}\text { 3. Patient's Qualification } \\
\text { Secondary School } \\
\text { Bachelor Degree } \\
\text { No Education } \\
\text { Diploma degree } \\
\text { Master's - Board degree } \\
\text { Ph.D. }\end{array}$ & $\begin{array}{l}445 \\
351 \\
89 \\
85 \\
34 \\
7\end{array}$ & $\begin{array}{l}45 \\
35 \\
8 \\
8 \\
4 \\
0\end{array}$ \\
\hline $\begin{array}{ll}\text { 4. } & \text { City } \\
\text { Riyadh } \\
\text { Makkah } \\
\text { Aseer Province } \\
\text { Qassim } \\
\text { Eastern Province } \\
\text { Almadinah } \\
\text { Hail } \\
\text { Tabuk } \\
\text { Najran } \\
\text { Jazan } \\
\text { Aljouf } \\
\text { Northern Borders Region } \\
\text { Albaha }\end{array}$ & $\begin{array}{l}389 \\
167 \\
110 \\
102 \\
97 \\
49 \\
30 \\
16 \\
14 \\
12 \\
11 \\
10 \\
4\end{array}$ & $\begin{array}{l}40 \\
18 \\
10 \\
10 \\
10 \\
4 \\
3 \\
1 \\
1 \\
1 \\
1 \\
1 \\
0\end{array}$ \\
\hline Questions related to Knowledge and awareness about Dental Floss & Frequency & Percentage $(\%)$ \\
\hline $\begin{array}{l}\text { 5. How often do you clean your tooth } \\
\text { Twice a day } \\
\text { Once a day } \\
\text { Sometimes } \\
\text { Three times a day } \\
\text { Never } \\
\end{array}$ & $\begin{array}{l}381 \\
329 \\
165 \\
109 \\
27\end{array}$ & $\begin{array}{l}39 \\
33 \\
16 \\
10 \\
2\end{array}$ \\
\hline $\begin{array}{l}\text { 6. How do you clean your tooth? } \\
\text { toothbrush and toothpaste } \\
\text { mouthwash } \\
\text { miswak } \\
\text { finger } \\
\text { toothbrush and tooth powder } \\
\text { I don't clean my teeth } \\
\end{array}$ & $\begin{array}{l}971 \\
234 \\
177 \\
38 \\
15 \\
12\end{array}$ & $\begin{array}{l}55 \\
23 \\
17 \\
3 \\
1 \\
1\end{array}$ \\
\hline $\begin{array}{l}\text { 7. What type of tooth brush method you employ to brush } \\
\text { your teeth? } \\
\text { Circular Motion } \\
\text { horizontal Motion } \\
\text { vertical Motion }\end{array}$ & $\begin{array}{l}570 \\
478 \\
346\end{array}$ & $\begin{array}{l}46 \\
37 \\
17\end{array}$ \\
\hline $\begin{array}{l}\text { 8. What secondary methods you use for plaque control? } \\
\text { Dental floss } \\
\text { Toothpicks } \\
\text { None } \\
\text { Inter-dental brushes } \\
\text { any pointy objects }\end{array}$ & $\begin{array}{l}406 \\
306 \\
270 \\
147 \\
113\end{array}$ & $\begin{array}{l}35 \\
25 \\
16 \\
14 \\
10\end{array}$ \\
\hline $\begin{array}{l}\text { 9. What do you mean by Dental floss? } \\
\text { A thread to clean between the teeth } \\
\text { None } \\
\text { An aid to whiten your teeth } \\
\text { a drug }\end{array}$ & $\begin{array}{l}875 \\
103 \\
30 \\
3\end{array}$ & $\begin{array}{l}86 \\
10 \\
4 \\
0\end{array}$ \\
\hline $\begin{array}{l}\text { 10. Do you know how to use dental floss? } \\
\text { Yes } \\
\text { No }\end{array}$ & $\begin{array}{l}597 \\
414 \\
\end{array}$ & $\begin{array}{l}60 \\
40 \\
\end{array}$ \\
\hline $\begin{array}{l}\text { 11. Did anyone recommend you of dental floss? } \\
\text { Yes } \\
\text { No }\end{array}$ & $\begin{array}{l}613 \\
398\end{array}$ & $\begin{array}{l}60 \\
40 \\
\end{array}$ \\
\hline
\end{tabular}




\begin{tabular}{|c|c|c|c|}
\hline & $\begin{array}{l}\text { Who recommended you about using dental floss? } \\
\text { Dentist } \\
\text { Friend / Relative } \\
\text { At university or school } \\
\text { Medical Doctor }\end{array}$ & $\begin{array}{l}449 \\
173 \\
38 \\
10\end{array}$ & $\begin{array}{l}68 \\
26 \\
5 \\
1\end{array}$ \\
\hline 13. & $\begin{array}{l}\text { Did your dentist explain to you how to use dental floss? } \\
\text { Yes } \\
\text { No }\end{array}$ & $\begin{array}{l}352 \\
659 \\
\end{array}$ & $\begin{array}{l}35 \\
65 \\
\end{array}$ \\
\hline 14. & $\begin{array}{l}\text { Do you think dental floss can make bleeding for the gum? } \\
\text { Yes } \\
\text { No }\end{array}$ & $\begin{array}{l}739 \\
272 \\
\end{array}$ & $\begin{array}{l}74 \\
26 \\
\end{array}$ \\
\hline 15. & $\begin{array}{l}\text { Did you see before video for the correct way of dental } \\
\text { floss? } \\
\text { Yes } \\
\text { No }\end{array}$ & $\begin{array}{l}260 \\
751\end{array}$ & $\begin{array}{l}25 \\
75\end{array}$ \\
\hline 16. & $\begin{array}{l}\text { Do you use dental floss? } \\
\text { Yes } \\
\text { No } \\
\text { Rarely }\end{array}$ & $\begin{array}{l}140 \\
566 \\
305\end{array}$ & $\begin{array}{l}14 \\
56 \\
30\end{array}$ \\
\hline 17. & $\begin{array}{l}\text { What was the reason to use dental floss? } \\
\text { oral hygiene } \\
\text { dental disease } \\
\text { bad breath }\end{array}$ & $\begin{array}{l}286 \\
173 \\
159\end{array}$ & $\begin{array}{l}46 \\
28 \\
26\end{array}$ \\
\hline 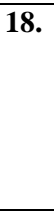 & $\begin{array}{l}\text { Type of dental floss used? } \\
\text { Don't know } \\
\text { Flavoured type } \\
\text { Unflavoured type } \\
\text { waxed type } \\
\text { Unwaxed type } \\
\end{array}$ & $\begin{array}{l}185 \\
102 \\
91 \\
38 \\
29 \\
\end{array}$ & $\begin{array}{l}44 \\
22 \\
20 \\
8 \\
6 \\
\end{array}$ \\
\hline 19. & $\begin{array}{l}\text { When do you use dental floss? } \\
\text { Don't focus } \\
\text { After brushing } \\
\text { before brushing }\end{array}$ & $\begin{array}{l}244 \\
139 \\
62\end{array}$ & $\begin{array}{l}54 \\
32 \\
14\end{array}$ \\
\hline 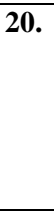 & $\begin{array}{l}\text { How often do u floss your teeth? } \\
\text { Rarely } \\
\text { once a day } \\
\text { Three times a week } \\
\text { once a week } \\
\text { I don't use floss }\end{array}$ & $\begin{array}{l}193 \\
108 \\
56 \\
46 \\
42 \\
\end{array}$ & $\begin{array}{l}44 \\
25 \\
12 \\
10 \\
9\end{array}$ \\
\hline 21. & $\begin{array}{l}\text { Rate the difficulty for using dental floss from } 1 \text { to } 10 \\
\text { (Average rating = 4.1) } \\
1 \\
2 \\
3 \\
4 \\
5 \\
6 \\
7 \\
8 \\
9 \\
10\end{array}$ & $\begin{array}{l}142 \\
31 \\
36 \\
36 \\
61 \\
46 \\
29 \\
26 \\
7 \\
31 \\
\end{array}$ & $\begin{array}{l}33 \\
7 \\
8 \\
8 \\
14 \\
10 \\
7 \\
5 \\
1 \\
8\end{array}$ \\
\hline 22. & $\begin{array}{l}\text { Does dental floss separate your teeth and make spaces? } \\
\text { Yes } \\
\text { No }\end{array}$ & $\begin{array}{l}171 \\
274\end{array}$ & $\begin{array}{l}38 \\
62\end{array}$ \\
\hline 23. & $\begin{array}{l}\text { How important is Flossing to you? } \\
\text { remove food remaining } \\
\text { prevent calculus between teeth } \\
\text { prevent stains between teeth } \\
\text { All of above }\end{array}$ & $\begin{array}{l}232 \\
32 \\
5 \\
176\end{array}$ & $\begin{array}{l}53 \\
7 \\
1 \\
39\end{array}$ \\
\hline & $\begin{array}{l}\text { Do you advice others to use dental floss? } \\
\text { Yes } \\
\text { No }\end{array}$ & $\begin{array}{l}419 \\
26\end{array}$ & $\begin{array}{l}95 \\
5\end{array}$ \\
\hline
\end{tabular}

\section{DISCUSSION}

According to the world oral health report, the prevalence of periodontal diseases among the adult population in Saudi Arabia ranges from medium to high [6]. The one culture and belief that is followed by the population of Saudi Arabia to maintain their oral hygiene is the use of miswak that is a chewing stick from the tree Salvadora persica [7].

Determining the Knowledge and Awareness of the adult population about the dental processing system 
in Saudi Arabia will help us to design and implement the Oral Health Promotion programs to reduce the prevalence of periodontal diseases among the population of Saudi Arabia. The questionnaire prepared for this survey was initially formulated in Arabic and then was translated into Arabic, and the questions were validated.

The information of the adult patients attending the various dental clinics was asked to participate in the survey by answering the questionnaire. The demographic details of the patients like their age, gender, qualification, city of Residence, and University were reported. All the data that was collected and recorded was checked for the missing values and normality distribution. The obtained values were summarized as means $\pm \mathrm{SD}$ and percentages. The majority of the participants were females. The current survey has a large proportion of the adult population study belonging to the city of Riyadh. Only $14 \%$ of the participants of the study use dental floss for inter-dental cleansing, indicating a lack of oral health awareness among the Saudi adult population. $55 \%$ of these participants use toothbrush and toothpaste for cleaning teeth, and $17 \%$ used miswak to cleanse the teeth. According to the researches, social factors play an important and challenging role in implementing the preventive dental program in Saudi Arabia.

To implement the oral awareness, strategies need to improve the knowledge related to the oral health of the adult Saudi population through proper planning and to provide adequate resources for the training and education of the young dentists. Professionals should give information to the patient and should also explain the preventive measures for oral diseases.

\section{CONCLUSION}

The results of the present study showed multiple graphs that highlighted the unsatisfied achievements about the knowledge and awareness levels of oral hygiene in Saudi Arabia. This survey shows that only about $140(14 \%)$ of the participants use dental floss for oral health whereas $566(56 \%)$ never used any dental floss, and about $305(30 \%)$ rarely use the dental floss. An excellent educational model that focuses on imparting the knowledge about oral Health Care needs to be established. The oral health awareness needs to be emphasized in all the policies to assure the sustainability of oral health, regardless of the change in the economic status of the patient. The research over evidence-based approaches to Oral Healthcare needs to be updated. Thus this survey to determine the knowledge and awareness about the Saudi adult population related to the Dental floss in oral hygiene is found to be unsatisfactory and needs to be improved by taking the oral heal care programs for both the dentists as well as the patients.

\section{LIMITATIONS}

This study involves only the adult population, so we cannot generalize our findings to all the population of Saudi Arabia. The second drawback to this study is that this is a subjective descriptive survey study, and no objective tool was used to access the level of oral hygiene among all the 1011 participants.

\section{ETHICAL CONSIDERATIONS Compliance with ethical standards}

Ethical approval: This article contains a survey with human participants performed by all the participants of this research.

Conflict of interest: All the authors do not have any commercial associations that might pose or create a conflict of interest with information presented in this communication. No intramural or extramural funding supported any aspect of this work.

\section{REFERENCES}

1. Messer, L.B., Calache, H. (2012). Oral health attitudes and behaviours of final-year dental students. Eur J Dent Educ, 16(3):144-155

2. Mumtaz, R., Khan, A.A. (2009). A comparative evaluation of oral health knowledge, attitudes and practices of dental and pharmacy students of Riphah international university. Pak Oral Dent J. 29(1):131-6

3. Qualtrough, A., Burke, F. (1994). A look at dental aesthetics. Quintessence International, 25(1): 7-14

4. Manipal, S., Anand, Mohan, C.S., Kumar, D.L., Cholan, P.K., Ahmed, A., \& Adusumilli, P. (2014). The importance of dental aesthetics among dental students assessment of knowledge. Journal of International Society of Preventive Community Dentistry, 4(1):48-51.

5. World Health Organization. Prevention Methods and Programmes for Oral Health. Report of a WHO Expert. 